\title{
Social Media And Networking Technologies: An Analysis Of Collaborative Work And Team Communication
}

Ephraim A. Okoro, Howard University, USA

Angela Hausman, Howard University, USA

Melvin C. Washington, Howard University, USA

\begin{abstract}
Digital communication increases students' learning outcomes in higher education. Web 2.0 technologies encourages students' active engagement, collaboration, and participation in class activities, facilitates group work, and encourages information sharing among students. Familiarity with organizational use and sharing in social networks aids students who are expected to be facile in these technologies upon graduation (Benson, Filippaios, and Morgan, 2010). Faculty members become coaches, monitoring and providing feedback to students rather than directing activities. While Web 2.0 technologies, including social networks, may act as a distraction in a teaching environment, our findings suggest that effective social networking in learning environments sustain quality instruction and skills-development in business education.
\end{abstract}

Keywords: Digital Communication; Web 2.0 Technologies; Social Networks; Independent Learning; Collaborative Learning

\section{INTRODUCTION}

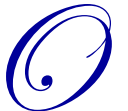

ver 175,000 new blogs and numerous new podcasts, webinars, videos, wikis, and other digital content emerge every day. Often the most practical and freshest information now resides online, rather than in textbooks or libraries (Katz and Gandel, 2008). Katz and Gandel (2008) contend the Web is "our most open university; a virtual place where people can gather around common interests" (p. 179). Students enrolled in colleges today learn differently (Dede, 2008). Today's students value independence and autonomy in determining how to learn (Barnes, Marateo, and Ferris, 2007). They also recognize limited need to memorize facts available at the touch of their laptop or tablet. Instead, students require tools for assimilating information, culling useful information from vast storehouses of information, determining which information is valid, and learning how to implement their new-found knowledge (Katz and Gandel, 2008).

Social networking fits this learning style. Students learn better, work independently and collaboratively, and acquire self-discipline through utilization of social networks and other Web 2.0 technologies (Zhao \& Kuh, 2004). Students also show an enduring commitment to knowledge acquired through social networks (Giannandrea, 2006; Magnoler, 2006). Faculties similarly perform more effectively in Web 2.0 environments (Hakane, Bakker, \& Schaufeli, 2006).

Selwyn (2009); however, acknowledges divergent opinions regarding Web 2.0 technologies, especially as they relate to students' learning outcomes. Detractors decry the de-powering of a "Google Generation" of learners incapable of independent critical thought, and generally hastening the mis-education of Generation M (Ziegler, 2007). Proponents advocate Web 2.0 technologies for increasing student performance and collaborative efforts (Selwyn, 2009). 
The best way to learn effective incorporation of Web 2.0 technologies in the classroom is from faculty who lead the way (Alexander, 2008). The goal of this paper is to share experiences and best practice advice from innovators in a business school. Other motivations include determining whether social networking tools and electronic media impact the quality of teaching as well as faculty-student pedagogical relationships. Zhao \& Kuh (2004) supports this notion, arguing that students find electronic interactions exciting, a source of fun, and an avenue for collaborative work with peers or classmates. Students also enjoy the bi-directionality of communication in social networks and prefer engaging in this context (Alexander, 2008).

\section{CURRENT TRENDS AND GROWTH OF SOCIAL NETWORKING}

Warren (2010) notes Web 2.0 technologies revolutionize teaching and learning, creating new challenges and opportunities in higher education. Learning by using Web 2.0 challenges students' ability to manage their time, to work independently, and collaborate with integrity. Mason \& Rennie (2008) emphasized that communication between students and faculty members is of paramount importance in ensuring accountability and responsiveness, and they argue that social networking is instrumental in achieving these objectives.

Web 2.0 technologies promote individual and group interactions and collaboration on important projects in universities. Further, they foster socialization, as well as serve as an immediate feedback mechanism for quality of learning control and assurance. Wandel (2007) determined that Web 2.0 sites, such as Friendster, MySpace, and Facebook, enable students to communicate more effectively with one another, discuss academic and social matters, and engage in rigorous and productive group projects.

\section{SOCIAL MEDIA AND NETWORKING CHANNELS}

The authors systematically incorporated Web 2.0 technologies into their classroom pedagogy. As faculty and students gained comfort, utilization of Web 2.0 increased. Marketing and business communication course content and objectives were redesigned and expanded, requiring increased students-faculty interaction mediated through technology, including Facebook groups, a blogging Web site, Blackboard, and a class website. Electronic media and social networking sites enhanced course materials and closely monitored students' research projects and other writing assignments.

Faculty used Blackboard to share content, supporting various learning styles. For instance, faculty shared PowerPoint presentations, video cases, quizzes, flashcards, and other materials suitable for kinetic, auditory, and visual learners. Homework, lecture notes, and discussion questions uploaded to Blackboard increased preparedness for classes, while supporting students unable to attend some classes.

Facebook formed an important implementation of Web 2.0 in classes. For instance, a Facebook group allowed shared knowledge initiated by students, as well as faculty. Similarly, students engaged each other, supporting excellence by providing direction, explanation, and moral support. Engagement not only reduced strains on faculty but resonate with students more. Warren (2010) explains these results, stating "Facebook facilitates social and academic communication, interaction in a 'trusted environment,' and provides a global context and impact." Increased engagement among students using a Facebook interface occurs in other classroom studies (Okoro, Cardon, and Washington, 2011).

Blogging also supported learning objectives. A class blog shared syllabi and reading assignments, much as Blackboard might, but also offered hyperlinks to other resources supporting student learning. The professor's blog offered additional instruction and required students' interaction which assesses their comprehension of complex constructs.

Even Google+ aided in student learning through hangouts - private visual chats.

Hangouts allowed student interaction with industry leaders who presented cutting-edge information and answered student questions from thousands of miles from campus. Because it most closely simulates face-to-face interactions, the increased adoption of Google+ promises great things for education. 


\section{SOCIAL MEDIA: BENEFITS AND CHALLENGES}

The following questions guide the assessment of the role, effectiveness, advantages, and drawbacks associated with social networking and electronic media: 1) What are the costs and benefits of electronic media and social networking? and 2) How can electronic media and social networking improve teaching and learning of business communication?

Studies (Mason \& Rennie, 2008) indicate that experiences gained teaching courses via electronic media are both challenging and enriching. First, students establish good friendships, build interpersonal relationships, and interact constantly among themselves. Second, students become partners in creative problem-solving. Electronic communication is especially effective for students who are reluctant to speak up in class. Young (2002) noted that this group of students provides feedback and responses to questions that enhance effective learning outcomes. They actively participate in discussions and make meaningful contributions to the subject-matter.

\section{ADVANTAGES}

Social networking, as a classroom tool, is a natural extension of students' use of Web 2.0 technologies in other aspects of their lives and interactions with peers. For example, the PEW Internet and American Life Project stated that more than half of all online teens use social networking (PEW, 2007). In fact, a recent study shows that over $50 \%$ of students already use Web 2.0 technologies to discuss school work with classmates (Arieanna, 2007). Increasingly, faculty members, administrators, and staff also use these technologies to communicate with their students (Wandel, 2007). Santovec (2006) cites Florida's Rollins College, Pennsylvania's Mansfield University, and the University of Alabama as leaders in using social networking sites to communicate with students.

Experiences utilizing Web 2.0 technologies in classes support their acceptance by students and increase the ability to bring emerging concepts, tactics, and other course content into the classroom. For instance, a presentation by the author of a best-selling Facebook book via Google+ provided insights to a social media class on appropriate utilization of new features introduced during the course of the semester. Requiring students to read and report findings from assigned blogs ensured the entire class learned emerging insights, tactics, and tools.

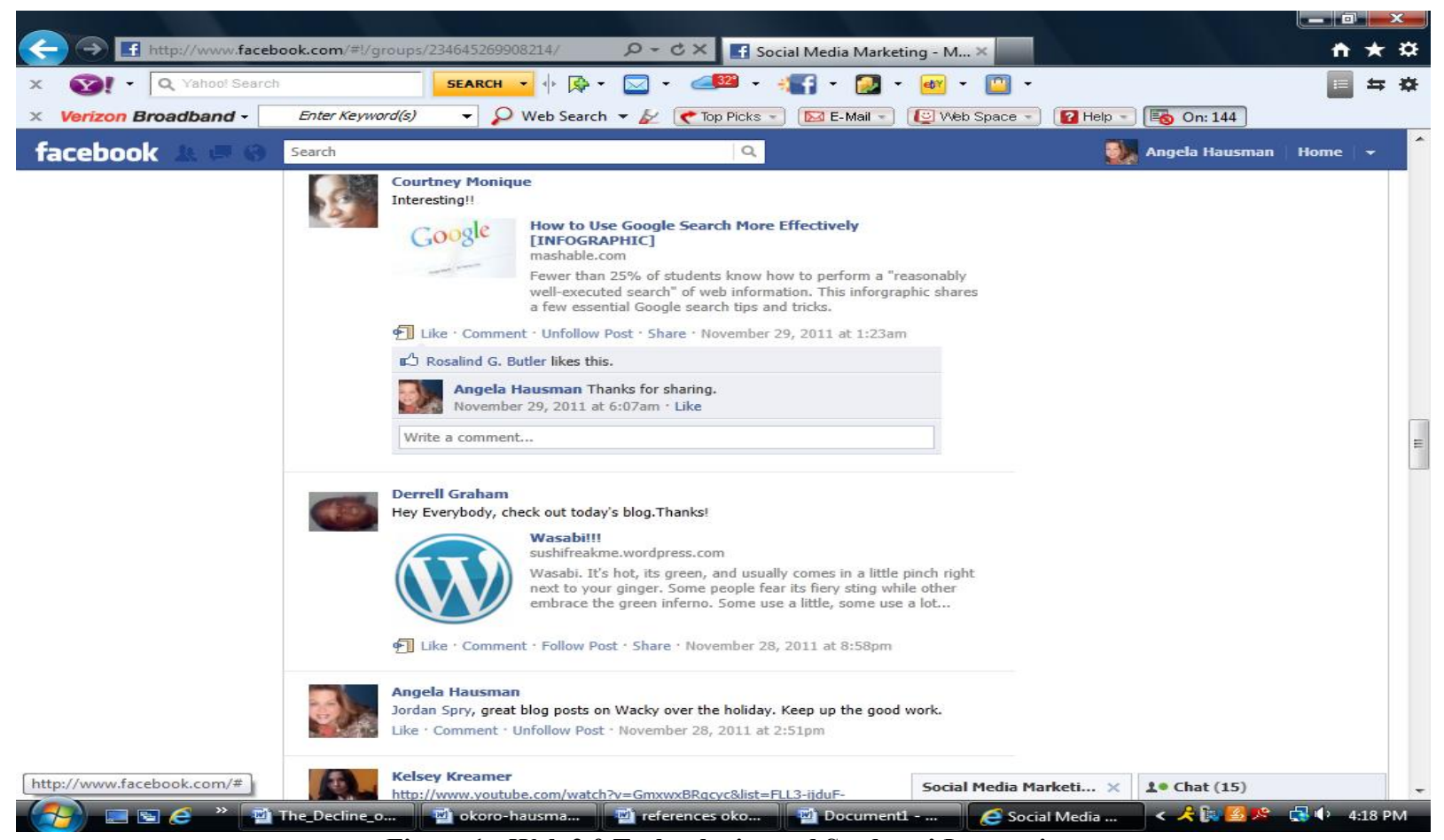

Figure 1: Web 2.0 Technologies and Students' Interaction 
Web 2.0 technologies support peer learning as well. Students shared learning and provided answers to questions that alleviated strain on faculty resources, while students were more comfortable asking questions of peers. Figure 1 is an example of this type of interaction.

Web 2.0 technologies also offer benefits for student management. Tracking student interactions, especially through Blackboard, provides a means for early identification of students facing failure and evaluating students (Bamina, 2007). Blackboard and Facebook messaging allow students to submit graded material securely and provide a vehicle for faculty to provide timely feedback on assignments. Meanwhile, communications are archived, cementing and clarifying expectations that might be murky with only verbal communication.

\section{CHALLENGES}

Web 2.0 technologies are not a panacea solving all higher education problems. For example, Nie (2001) argues that extensive use of the Internet or electronic media in teaching minimizes the critical role of face-to-face interactions with students in class sessions. Students' interactions and participation provide rich content support which makes sub-optimal trade-offs. They forgo attending classes for other activities, believing that online material is sufficient for learning and success. Additional drawbacks include students' low and inconsistent online participation, poor attendance, and inability to understand or comply with complex online instructions (Zhao \& Kuh, 2004). Web 2.0 technologies require more resources than traditional classroom teaching. First, creating Web 2.0 content is taxing for faculty, both in terms of their ability to master these technologies and finding the time necessary. Faculty members' ability to monitor or supervise social network activities is also time-consuming. Web 2.0 technologies also strain IT support, such as servers, bandwidth, and trained support personnel.

\section{CONCLUSION}

Evidence demonstrates that Web 2.0 technologies improve teaching and learning. Maximizing learning involves thorough pre-planning through content creation and curation and establishing rewards for electronic interaction. Electronic communication technologies should augment rich, face-to-face communication and support, not replace, interpersonal skills (Cardon \& Okoro, 2011). During the semester, faculty must monitor student interactions, provide timely feedback, and actively engage students. Faculty must also provide student training in effective use of online technologies to ensure all are comfortable (Wellman, Witte, \& Hampton, 2001)

\section{AUTHOR INFORMATION}

Ephraim A. Okoro, Ph.D. is an assistant professor of business communication and marketing at Howard University. His research interests probe the interface between intercultural communication and workforce diversity in the context of globalization. Address correspondence to Dr. Ephraim A. Okoro, Department of Marketing, School of Business, Howard University, 2600 - Sixth Street, NW, Washington, D.C. 20059; E-mail: eaokoro@howard.edu (Corresponding author)

Angela Hausman, Ph.D. is an associate professor of marketing at Howard University. She teaches marketing and conducts research in marketing and related areas. Her contact address is: Howard University, School of Business, Department of Marketing, 2600 - Sixth Street, NW, Washington, D.C. 20059; E-mail: hausman1229@gmail.com

Melvin C. Washington, $\mathrm{PhD}$ is an assistant professor of business and management communication at Howard University. His research focuses on organizational/business communication. His contact address is: Howard University School of Business, 2600 6th St., Washington, DC 20059; E-mail: m_c_washington@howard.edu

\section{REFERENCES}

1. Alexander, B. (2008). Social networking in the age of cloud computing. in The Tower and the Cloud: Higher education in the age of cloud computing, Robert N. Katz, ed. 197-201.

2. Arieanna (2007, August 21). Educational benefits of social networking. Education week. 
3. Bambina, A (2007). Online social support: The interplay of social networks and computer-mediated communication. Amherst, NY: Cambria Press.

4. Barnes, K., R. Marateo, and S. Ferris. 2007. Teaching and learning with the Net Generation. Innovate 3 (4).http://www.innovateonline.info/index.php?view=article\&id=382 Archived at http://www.webcitation.org/5Xw2qkEa6.

5. Cardon, P. \& Okoro, E. (2010 December). A measured approach to adopting new media in the business communications classroom." Business Communication Quarterly, 73(4), 434-438.

6. Dede, C. (2008, May/June). A seismic shift in epistemology. EDUCAUSE Review 80.

7. Hakanen, J., Baker, A.B. and Schaufeli, W.B. (2006). Burnout and work engagement among Teachers.” The Journal of School Psychology, Volume 43, 495-513.

8. Katz, R.N. and Gandel, P.B. (2008), The tower, the cloud, and posterity," in The Tower and the Cloud: Higher education in the age of cloud computing, Robert N. Katz, ed. 172-189.

9. Mason, R., \& Rennie, F. (2008). Learning and social networking handbook: Resources for higher education. USA: Routledge.

10. Nie, H.H. (2001). Sociability, interpersonal relations, and the Internet: Reconciling conflicting findings. American Behavioral Scientist, 45 (3), 420-435.

11. Pew Research Center's Internet and American Life Project (2007). http://www.pewinternet.org

12. Okoro, E., Cardon, P., \& Washington, M. (2011, September). "E-Portfolios in business communication courses as tools for employment." Business Communication Quarterly.

13. Santovec, M.L. (2006, March). Using online networking to engage and retain students. Recruitment and retention in higher education, 20 (3), 1, 3, 75.

14. Selwyn, N. (2009, June). Faceworking: Exploring students' education-related use of Facebook. Learning Media and Technology, Volume 34, No2, (157-174)

15. Wandel, T. (2007, July). About Facebook: Educational institution responses to online social networking. WCA Conference, Brisbane.

16. Warren, M. (2010). Security risks of social networking systems (Keynote Presentation), $4^{\text {th }}$ IEE International Conference on Network and Systems Security, Melbourne, Australia.

17. Wellman, B., Haase, A.Q., Witte, J., \& Hampton, K. (2001). Does the internet increase, Decrease, or supplement social capital? Social networks, participation, and Community commitment. American Behavioral Scientist, 45(3), 436-455.

18. Young, J. (2002, February 21). Creating online portfolios can help students see 'Big Picture,' colleges say. Chronicle of Higher Education, http://chronicle.com/ free/200202210t.htm.

19. Ziegler, S.G. (2007). The (mis)education of Generation M. Learning, Media and Technology, 32 (1), (2007), 69-81.

20. Zhao, C. \& Kuh, G. (2004). Adding value: Learning communities and student engagement, Research in Higher Education, 45 (2), 115-138. 
NOTES 